\title{
Epidemiologic and clinical profile of human Papilloma virus infection in the department of Dermatology-Venerology of the Donka National Hospital in Conakry, Guinea
}

\author{
Sako $\mathrm{FB}^{1,2^{*}}$, Soumah $\mathrm{MM}^{2,3}$, Bangoura $\mathrm{MA}^{2,4}$, Tounkara $\mathrm{TM}^{2,3}$, Traoré $\mathrm{FA}^{1,2}$, Maiga $\mathrm{A}^{3,5}$, Keita $\mathrm{F}^{2,3}$, Diané BF ${ }^{2,3}$, Keita $\mathrm{M}^{2,3}$, Baldé $\mathrm{H}^{2,3}$, \\ Delamou $A^{2,6}$, Touré $A^{2}$ and Cissé $M^{2,3}$
}

*Correspondence: sakofb@yahoo.fr

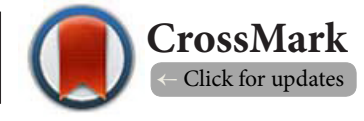

'Infectious and Tropical Diseases department, National hospital of Donka.

${ }^{2}$ Gamal Abdel Nasser University of Conakry.

${ }^{3}$ Dermatology Venerology department, National hospital of Donka.

${ }^{4}$ Pediatry Departement, National hospital of Donka.

${ }^{5}$ Kofi Annan University of Guinea.

${ }^{6}$ National Training and Research Centre in Rural Health of Mafèrinyah, Forécariah, Guinea.

\begin{abstract}
Objective: The objective of this study was to determine the prevalence and factors associated with human Papilloma virus infection in the department of Dermatology-Venerology of the Donka National Hospital in Conakry, Guinea.

Methods: This was a descriptive and analytical cross-sectional study over a 6-month period (from 1 November 2016 to 30 April 2017). We included patients visiting the department of Dermatology-Venereology of the Donka National Hospital of Conakry.

Results: Of the 3,000 patients visiting the facility during the study period, 327 had clinical symptoms of HPV infection (10.90\%) with a female and younger-aged predominance. 60.24\%were respectively single. Clinical symptoms were mainly common warts (30.58\%), flat warts (18.65\%), and plantar warts (13.15\%)and the most frequent locations were the upper limbs (42.20\%), the vulvovaginal region $(24.46 \%)$ and the forehead $(19.57 \%)$. Factors associated with mucosal infection were HIV infection, history of sexually transmitted infection, multiple sexual partnership while the tropism location were associated withmicro trauma and erosions.
\end{abstract}

Conclusion: Human papilloma virus infections are common in our context with various clinical presentations and locations. The risk factors vary according to the type of infection's tropism (mucosal or cutaneous tropism).

Keywords: Epidemiology, clinical, risk factors, HPV, tumors

\section{Introduction}

Infection with human papillomavirus (HPV) is a real public health problem with an overall incidence of more than 30 million new cases per year, and probably the most common viral sexually transmitted infection in the world [1]. HPVs infect the skin (warts) and mucous membranes (condylomas), particularly squamous epithelia, and are classified according to their cutaneous or mucosal tropism [2]. More than $120 \mathrm{HPV}$ genotypes are known to cause pathologies of varying severity, ranging from warts to neoplasia. These viruses are transmitted more particularly, but not exclusively, through sex, and are associated with cervical cancer [3-6]. High-risk oncogenic HPV infections account for $5.2 \%$ of all cancers worldwide, $2.2 \%$ of cancers in developed countries and $7.7 \%$ in developing countries [7]. In several studies, $75 \%$ of women have been exposed to HPV in their lifetime $[2,8,9]$ and those aged 15 to 25 are the most affected $[4,9]$. The highest prevalence $(>20 \%)$ is observed in Africa and Central America [2].

Prevalence rates of anogenital warts in sub-Saharan Africa among female sex workers and women with STIs range from $2.9 \%$ to $10.7 \%$. In men, prevalence rates range from $4.1 \%$ to $4.8 \%$ in West and Central Africa [10]. The main factors associated with HPV infection are gender, age, race, socio-demographic characteristics, sexual behavior, history of sexually transmitted infections, parity, contraceptive methods, and smoking [11]. Few authors have studied the association between HPV infec- 
Sako et al. Research Journal of Infectious Diseases 2018,

http://www.hoajonline.com/journals/pdf/2052-5958-6-1.pdf

doi: $10.7243 / 2052-5958-6-1$

tion and sex since most of these studies are conducted only in women [11]. About $12 \%$ of women with normal cervical smears show cervical HPV carriage detected by molecular biology, with women in sub-Saharan Africa showing the highest prevalence (24\%) compared to women from Eastern Europe (21\%) or Latin America (16\%) [12]. It is important to note that sub-Saharan Africa has the highest prevalence of cervical HPV infection in the world, with some prevalence reported particularly high, such as in Guinea (48\%) and Mozambique $(41 \%)[13,14]$.

In 2009, Keita et al. [15] reported an overall prevalence of $50.8 \%$ HPV in a population of 996 women with or without cervical cancer in Conakry (Guinea). However, there is still a lack of knowledge about the prevalence of this infection in the Guinean hospital context.

The objective of this study was to determine the prevalence and factors associated with human Papilloma virus infection in the department of Dermatology-Venereology of the Donka National Hospital.

\section{Methods}

Our study was conductedin the Dermatology and Venereology Department of the Donka National Hospital of Conakry. This department is the only one of its kind in the Conakry Teaching Hospital of and the country. It receives an average of 500 patients per month.

This was a descriptive and analytical cross-sectional study over a 6-month period (from 1 November 2016 to 30 April 2017). We included patients admitted and treated in the department who voluntarily accepted to participate in the study. The diagnosis of HPV infection was made based on the clinical features of the lesions examined by a dermato-venerologist. Patients were randomly recruited. The minimum sample size was estimated at $\mathrm{N}=3000$ to allow the recruitment of a representative number of cases of HPV infection. The probing step was six (3000/500) and the first individual was randomly assigned the number three. Consecutively, each sixth patient admitted to the departmentwasselected and asked for his participation in the study (e.g. Patients $3,9,15,21, \ldots$ ).

Data was collected using a standardized questionary focused on socio-demographic variables (age, sex, marital status, occupation and educational level) and clinical variables (type of clinical symptoms and location of lesions). The analysis of factors associated with HPV infection was performed differently depending on whether the viral tropism was mucosal (age of first sexual intercourse, use of a protective device during sexual intercourse, serological status in the HIV test, history of sexually transmitted infection (STI) and number of sexual partners) or cutaneous (micro trauma or erosion).Data was analysed using Epi info version 7.2 software (CDC Atlanta, USA). The qualitative variables were compared by the chi2 test. Factors associated with HPV infection were identified using bivariate analysis and simple logistic regression with a significance level set at $5 \%$.

\section{Results}

Of the 3,000 patients visiting the facility during the study period, 327 (10.9\%) had clinical symptoms of HPV infection (Table 1). Female gender was predominant with a sex ratio of 0.61 . The mean age was $26.52 \pm 15.74$ years ranging 5 to 74 years. Most of our study participant weresingle (60.24\%) and had at least a primary level of education (72.17\%). In our context, the most common clinical symptoms were common warts (Figure 3) ( $\mathrm{N}=100,30.58 \%)$, verruciform epidermodysplasia ofLutz-Lewandowski with acuminate condyloma (Figure 1) $(\mathrm{N}=68 ; 20.80 \%)$ and flat warts $(\mathrm{N}=61.65 \%)$ (Table 2).The main location of the lesions was the oral cavity. The most frequent locations were the upper limbs ( $N=38 ; 42.20 \%)$, the vulvovaginal area (Figure 2$)(\mathrm{N}=80 ; 24.46 \%)$, the forehead ( $\mathrm{N}$ $=64 ; 19.57 \%)$ and the soles of the feet $(\mathrm{N}=42 ; 12.84 \%)$. Factors

Table 1. Sociodemographic characteristics of 327 patients diagnosed with a HPV infection in the department of Dermatology-Venereology of the Donka National hospital, 1st November 2016 to 30th April 2017.

\begin{tabular}{|c|c|c|c|}
\hline \multirow[t]{2}{*}{ Characteristics } & \multicolumn{2}{|c|}{ Sex } & \multirow[t]{2}{*}{ Total $\mathbf{n}=\mathbf{3 2 7}$} \\
\hline & Female $n=203$ & Male $n=124$ & \\
\hline Sex-ratio & 0.61 & & \\
\hline Mean Age & 27.47 & 24.97 & $26.52 \pm 15,74$ \\
\hline \multicolumn{4}{|l|}{ Marital status } \\
\hline $\begin{array}{l}\text { - Single } \\
\text { - Divorced } \\
\text { - Widow (er) } \\
\text { - Monogamous married } \\
\text { - Polygamous married }\end{array}$ & $\begin{array}{l}122(61.93 \%) \\
4(57.14 \%) \\
7(58.33 \%) \\
49(62.03 \%) \\
20(62.50 \%)\end{array}$ & $\begin{array}{l}75(38.07 \%) \\
3(42.86 \%) \\
5(41.67 \%) \\
30(37.97 \%) \\
12(37.50 \%)\end{array}$ & $\begin{array}{l}197(60.24 \%) \\
7(2.14 \%) \\
12(3.67 \%) \\
79(24.16 \%) \\
32(9.78 \%)\end{array}$ \\
\hline \multicolumn{4}{|l|}{ Occupation } \\
\hline $\begin{array}{l}\text { - Student / Pupil } \\
\text { - Civil servant } \\
\text { - Trader } \\
\text { - Jobless } \\
\text { - Others }\end{array}$ & $\begin{array}{l}69(62,16 \%) \\
35(61,40 \%) \\
30(62,25 \%) \\
9(60 \%) \\
60(62,50 \%)\end{array}$ & $\begin{array}{l}42(37,84 \%) \\
22(38,60 \%) \\
18(37,50 \%) \\
6(40 \%) \\
36(37,50 \%)\end{array}$ & $\begin{array}{l}111(33,94 \%) \\
57(17,43 \%) \\
48(14,68 \%) \\
15(4,59 \%) \\
96(29,36 \%)\end{array}$ \\
\hline \multicolumn{4}{|l|}{ Education level } \\
\hline $\begin{array}{l}\text { - Scholed } \\
\text { - Unscholed }\end{array}$ & $\begin{array}{l}147(62,29 \%) \\
57(62,63 \%)\end{array}$ & $\begin{array}{l}89(37,71 \%) \\
34(37,37 \%)\end{array}$ & $\begin{array}{l}236(72,17 \%) \\
91(27,83 \%)\end{array}$ \\
\hline
\end{tabular}

Table 2. Clinical symptoms distribution among 327 patients with HPV infection in the Dermatology-Venerology Department of the Donka National Hospital, November 1st, 2016 to April 30th, 2017.

\begin{tabular}{lll}
\hline $\begin{array}{l}\text { Clinical symptoms of the HPV } \\
\text { infection }\end{array}$ & Count & Proportion (\%) \\
\hline Vulgar warts & 100 & 30.58 \\
Flat warts & 61 & 18.65 \\
Flat warts & 43 & 13.15 \\
EVLL** & 3 & 0.92 \\
Acuminous condyloma & 68 & 20.80 \\
Flat condyloma & 20 & 6.12 \\
Papular condyloma & 18 & 5.50 \\
Giant condyloma & 14 & 4.28 \\
Total & 327 & 100.00 \\
\hline
\end{tabular}

* : myrmecy (26), mosaic (17)

${ }^{* *}$ : verruciform epidermodysplasia of Lutz-Lewandowski 


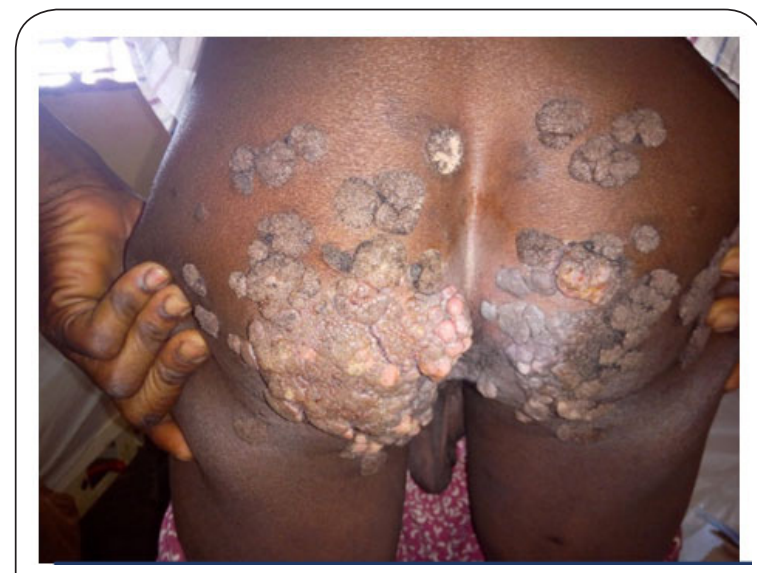

Figure 1. Acuminate condyloma located on the gluteal and anal region in a 35 -year old patient.

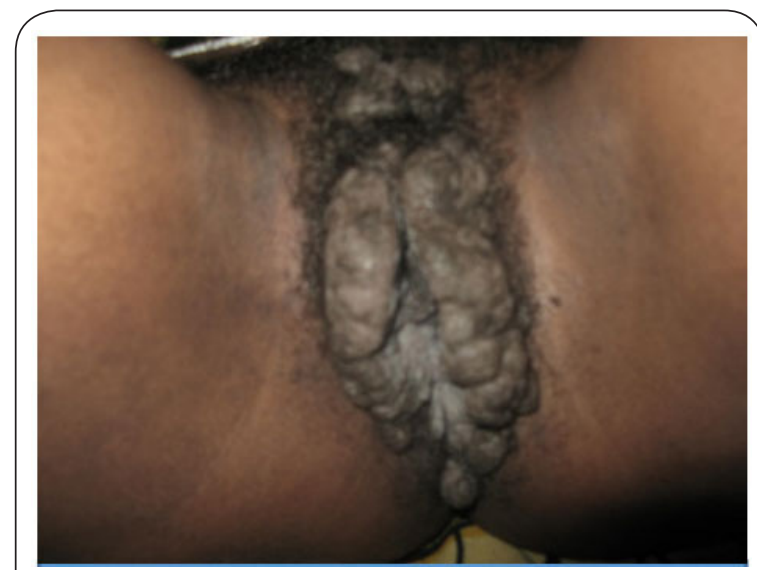

Figure 2. Vulvar giant acuminate condyloma in a 29-yearold patient.

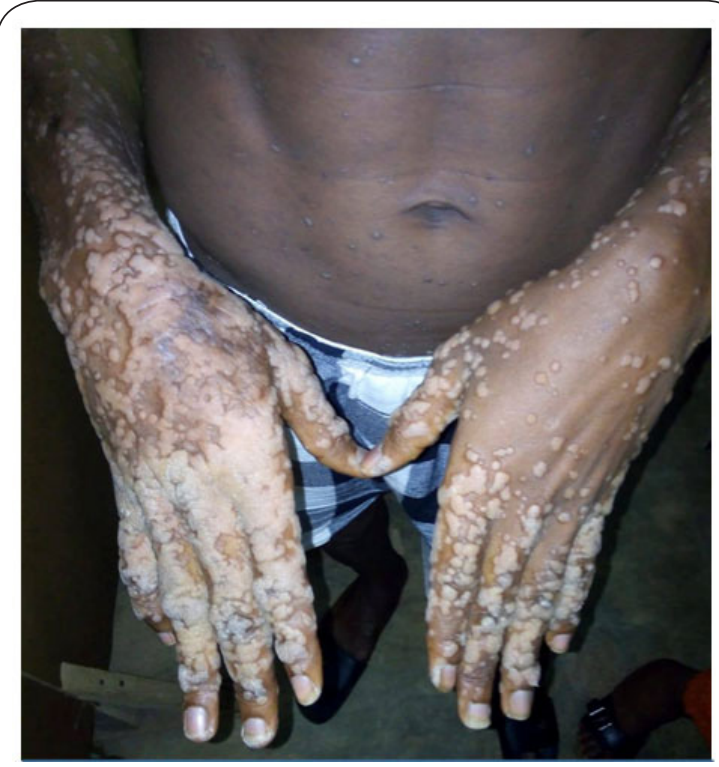

Figure 3. Vulgar disseminated wart in a 29-year old patient. associated with mucosal infection were HIV infection (OR=3.21, 95\%Cl: 2.31-4-48), history of STIs (OR=3.89, 95\% Cl: 2.83-5.35) and the multiple sexual partnership (OR=12.81, 95\% Cl: 9.3517.64). Factors associated with the risk of occurrence of skin tropism were micro trauma ( $\mathrm{OR}=1.59,95 \% \mathrm{Cl}: 1.10-2.30)$ and erosions ( $\mathrm{OR}=1.32,95 \% \mathrm{Cl}$ : 0.84-2.05).

\section{Discussion}

This study is one of the first to evaluate the prevalence of HPV infection in Guinean hospital setting, thus filling a local gap of knowledge on the subject and adding to the existing body of literature in sub-Saharan Africa.

In the literature, the prevalence of HPV infection varies according to the country and population. A $26 \%$ proportion has been reported in Africa while Asia seems less affected conservative $(8 \%)[8,11]$. HPV infections with a high risk of cancer (such as serotypes 16 and 18 ) are more prevalent $(66.7 \%$ of serotypes) than those with low risk (27.7\%), regardless of the region of the world $[8,16]$. In general, HPV type 16 is the most prevalent in the world with an estimated prevalence of $26.3 \%$ [16].

We have recorded a female predominance as already reported in several studies [2-9]. Although most of researches have focused on HPV infection in women because of the association between HPV infection and cervical cancer, very few studies in men have found prevalence as high as those reported in studies conducted in women [16].

The patients in our study were relatively young. It is known that HPV infection is more common in the age group of 20 to 29 years [11]. After 30 years, the prevalence of HPV decreases rapidly. Moststudies $[8, \mathbf{1 1}, \mathbf{1 7}, \mathbf{1 8}]$ demonstrate an inverse association between age and HPV infection, except those with very homogeneous populations in terms of age. The decrease in the prevalence of HPV with age seems independent from sexual activity [11].

Warts were the most common clinical symptoms in our study, followed by condyloma with various locations. Common vulgar warts are located mainly on the back of the hands and fingers; they are more rarely palmar. Their number varies from a few units to several tens and they are sometimes confluent. Periungual and subungual warts may give rise to nail changes. The other locations are less frequent (face, scalp) where they assume the appearance of large warts arranged around the orifices or screening the cervical and bearded region (selfinoculation by shaving) and the flat common warts that sit with predilection on the face, on the back of the hands and on the limbs [19].

Although condylomas are benign, they are often poorly supported psychologically and recurrences after treatment are common, thus leading to high management costs $[\mathbf{2 , 2 0 ]}$. The prevention and management of HPV infections in Africa is gradually expanding beyond national boundaries. However, no country in sub-Saharan Africa has so far been able to cope alone with the high, unavoidable, costs of tackling this 
Sako et al. Research Journal of Infectious Diseases 2018,

http://www.hoajonline.com/journals/pdf/2052-5958-6-1.pdf

doi: $10.7243 / 2052-5958-6-1$

emerging public health challenge at all levels [21].

We found vulvovaginal, oral and perianal mucosal sites that could be related to genito-genital, genito-oral and genitoanal traumatising sexual practices. In fact, the lesions are more frequent in the regions traumatized during the sexual intercourse and can be single or multiple.

In our study, we found that HIV infection, history of sexually transmitted infection (STI), and multiple sexual partnership were significantly associated with mucosal tropism HPV infection while micro trauma and erosions were associated with cutaneous tropism HPV infection. Patients who first had sex between the ages of 11 and 20, those who tested positive for HIV, those who reported a history of STIS, and those who reported more than one sexual partner were more likely to have an infection of HPV. The total number of sexual partners and the number of recent partners appear to beconsistent determinants of HPV infection, especially for oncogenic strains [11]. Co-infection with HIV, which is highly prevalent among sexually active women in sub-Saharan Africa, is a cofactor that facilitates carcinogenesis associated with HPV-HR infections. Indeed, HPV-HR infections are nearly 5-fold more common in HIV-infected women [22], who have a 40 -fold higher risk of developing high-grade intraepithelial lesions $[22,23]$, and a 2 to 22 -fold higher probability of developing cervical cancer than HIV-negative women [23]. In parallel with the different specific actions carried out within the framework of AIDS programs, the implementation of public health interventions in Africa for the prevention, diagnosis and management of HPV infections and cervical cancer lesions will have to follow a programmatic progression at regional and then national level. In the field of care, the means of diagnosis and curative tools, as well as medical and socio-community agent, follow at national level the organization of the health pyramid [24].

Our study had limitations. Because the study was carried out in a national reference service for dermatological and venereological diseases, its results might not be generalized to the entire Guinean population. In addition, we could not determine the different serotypes of HPV. Nevertheless, it has provided useful information on the epidemiologic and clinical profile of HPV infections in Guinean hospitals.

\section{Conclusion}

This study shows that infection with human papilloma virus (HPV) is common in our context with various clinical presentations affecting the skin and mucous membranes. The main associated factors were HIV infection, history of sexually transmitted infection and multi sexual partnership for mucosal infections; microtrauma and erosions for skin tropism infections.

A study including virological aspects would better help understand the involvement of other factors in the occurrence of HPV infection in Guinea.

\section{Competing interests}

The authors declare that they have no competing interests.

\section{Authors' contributions}

\begin{tabular}{|l|c|c|c|c|c|c|c|c|c|c|c|c|c|}
\hline Authors' contributions & SFB & SMM & BMA & TTM & TFA & MA & KF & DBF & KM & BH & DA & TA & CM \\
\hline Research concept and design & $\checkmark$ & $\checkmark$ & $\checkmark$ & $\checkmark$ & $\checkmark$ & $\checkmark$ & $\checkmark$ & $\checkmark$ & $\checkmark$ & $\checkmark$ & $\checkmark$ & $\checkmark$ & $\checkmark$ \\
\hline Collection and/or assembly of data & $\checkmark$ & $\checkmark$ & $\checkmark$ & $\checkmark$ & $\checkmark$ & $\checkmark$ & $\checkmark$ & $\checkmark$ & $\checkmark$ & $\checkmark$ & $\checkmark$ & $\checkmark$ & $\checkmark$ \\
\hline Data analysis and interpretation & $\checkmark$ & $\checkmark$ & $\checkmark$ & $\checkmark$ & $\checkmark$ & $\checkmark$ & $\checkmark$ & $\checkmark$ & $\checkmark$ & $\checkmark$ & $\checkmark$ & $\checkmark$ & $\checkmark$ \\
\hline Writing the article & $\checkmark$ & $\checkmark$ & $\checkmark$ & $\checkmark$ & $\checkmark$ & $\checkmark$ & $\checkmark$ & $\checkmark$ & $\checkmark$ & $\checkmark$ & $\checkmark$ & $\checkmark$ & $\checkmark$ \\
\hline Critical revision of the article & $\checkmark$ & $\checkmark$ & $\checkmark$ & $\checkmark$ & $\checkmark$ & $\checkmark$ & $\checkmark$ & $\checkmark$ & $\checkmark$ & $\checkmark$ & $\checkmark$ & $\checkmark$ & $\checkmark$ \\
\hline Final approval of article & $\checkmark$ & $\checkmark$ & $\checkmark$ & $\checkmark$ & $\checkmark$ & $\checkmark$ & $\checkmark$ & $\checkmark$ & $\checkmark$ & $\checkmark$ & $\checkmark$ & $\checkmark$ & $\checkmark$ \\
\hline Statistical analysis & $\checkmark$ & $\checkmark$ & $\checkmark$ & $\checkmark$ & $\checkmark$ & $\checkmark$ & $\checkmark$ & $\checkmark$ & $\checkmark$ & $\checkmark$ & $\checkmark$ & $\checkmark$ & $\checkmark$ \\
\hline
\end{tabular}

\section{Acknowledgement}

We are grateful to all the patients who have kindly facilitated the realization of this work.

Publication history

EIC: Ishtiaq Qadri, King Abdul Aziz University, Saudi Arabia.

Received: 01-Mar-2018 Final Revised: 16-April-2018

Accepted: 18-April-2018 Published: 04-May-2018

\section{References}

1. Scheurer ME, Tortolero-Luna G and Adler-Storthz K. Human papillomavirus infection: biology, epidemiology, and prevention. Int J Gynecol Cancer. 2005; 15:727-46. | Article | PubMed

2. Louie K, Didelot MN, Damay A, Nagot N, Mayaud P and Segondy M. Papilloma virus humains (HPV) et cancers associés: aspects épidémiologiques. Revue francophone des laboratoires. 2008; 405:2734. | Article
3. Duport N. Données épidémiologiques sur le cancer du col de l'utérus - état des connaissances - Actualisation. Institut de Veille Sanitaire, France. 2008.

4. Organisation Mondiale de la Santé (OMS). La lutte contre le cancer du col de l'utérus : guide des pratiques essentielles. OMS, Genève 2007.

5. Kjaer SK, Chackerian B, van den Brule AJ, Svare EI, Paull G, Walbomers 
JM, Schiller JT, Bock JE, Sherman ME, Lowy DR and Meijer CL. Highrisk human papillomavirus is sexually transmitted: evidence from a follow-up study of virgins starting sexual activity (intercourse). Cancer Epidemiol Biomarkers Prev. 2001; 10:101-6. | Article | PubMed

6. Siracusano $S$, Silvestri $T$ and Casotto $D$. Sexually transmitted diseases: epidemiological and clinical aspects in adults. Urologia. 2014; 81:200-8. | Article | PubMed

7. Parkin DM. The global health burden of infection-associated cancers in the year 2002. Int I Cancer. 2006; 118:3030-44. | Article | PubMed

8. Gavillon N, Vervaet $H$, Derniaux E, Terrosi P, Graesslin $\mathrm{O}$ and Quereux C. Papillomavirus humain (HPV) : comment ai-je attrapé ça ?How did I contract human Papillomavirus (HPV)? Gynécologie Obstétrique et Fertilité. 2010; 38:199-204. | Article

9. Ouedraogo CM, Djigma FW, Bisseye C, Sagna T, Zeba M, Ouermi D, Karou SD, Pietra V, Buelli F, Ghilat-Avoid-Belem NW, Sanogo K, Sempore J, Moret R, Pignatelli S, Nikiema JB and Simpore J. [Epidemiology, characterization of genotypes of human papillomavirus in a population of women in Ouagadougou]. J Gynecol Obstet Biol Reprod (Paris). 2011; 40:633-8. | Article | PubMed

10. Ghedamsi S, Mokhtar I, Ben Tekaya N, Kharfi M, Zghal M and Ridha Kamoun M. Profil épidémio-clinique des condylomes dans un service de dermatologie. A propos de 232 cas. La Tunisie médicale. 2000; 78:723726.

11. Akom $E$ and Venne S. L'infection au virus du papillome humain (VPH). Institut national de santé publique du Québec. 2003; 114-10. I Website

12. Bruni L, Diaz M, Castellsague X, Ferrer E, Bosch FX and de Sanjose S. Cervical human papillomavirus prevalence in 5 continents: metaanalysis of 1 million women with normal cytological findings. J Infect Dis. 2010; 202:1789-99. | Article | PubMed

13. De Vuyst H, Alemany L, Lacey C, Chibwesha CJ, Sahasrabuddhe V, Banura $C$, Denny $L$ and Parham GP. The burden of human papillomavirus infections and related diseases in sub-saharan Africa. Vaccine. 2013; 31 Suppl 5:F32-46. | Article | PubMed Abstract | PubMed FullText

14. Ferlay J, Soerjomataram I, Dikshit R, Eser S, Mathers C, Rebelo M, Parkin $\mathrm{DM}$, Forman $\mathrm{D}$ and Bray F. Cancer incidence and mortality worldwide: sources, methods and major patterns in GLOBOCAN 2012. Int J Cancer. 2015; 136:E359-86. | Article | PubMed

15. Keita N, Clifford GM, Koulibaly M, Douno K, Kabba I, Haba M, Sylla BS, van Kemenade FJ, Snijders PJ, Meijer CJ and Franceschi S. HPV infection in women with and without cervical cancer in Conakry, Guinea. $\mathrm{BrJ}$ Cancer. 2009; 101:202-8. | Article | PubMed Abstract | PubMed FullText

16. Clifford GM, Rana RK, Franceschi S, Smith JS, Gough G and Pimenta JM. Human papillomavirus genotype distribution in low-grade cervical lesions: comparison by geographic region and with cervical cancer Cancer Epidemiol Biomarkers Prev. 2005; 14:1157-64. | Article | PubMed

17. Paavonen J. Human papillomavirus infection and the development of cervical cancer and related genital neoplasias. Int J Infect Dis. 2007; 11 Suppl 2:S3-9. | Article | PubMed

18. Baldauf JJ, Hamid D, Ritter J and Halter P. Néoplasies intraépithéliales du col. Ecycl Med Chir (Editions scientifiques et médicales Elsevier, Paris). Gynécologie. 2003; 597:169-83.

19. Collège des Enseignants Dermatologie de France (CEDEF). Tumeurs cutanées épithéliales et mélaniques : tumeurs à papilloma virus humain (HPV). Anales de Dermatologie et Vénéréologie. 2012; 139:A144-A149.

20. Lacey CJ, Lowndes CM and Shah KV. Chapter 4: Burden and management of non-cancerous HPV-related conditions: HPV-6/11 disease. Vaccine. 2006; 24 Suppl 3:S3/35-41. | Article | PubMed

21. Berthet N, Berling C, Nabi H, Woto Gaye G, Toure Kane C, Diop-Ndiaye $\mathrm{H}$, Koumakpayi IH, Engohan Aloghe C, Bisvigou U, Didi Coulibaly J, Faye Kette H, Koffi E, Ekra D, Moussavou Boundzanga P, Labouba I, R NJ, Tebeu PM, Sandjong I, Atangana PA, N'Kegoum B, Rakoto-Andrianarivelo M, Rakotomalala FA, Randrianjafisamindrakotroka N, Andriamampionona TF, Ratovohery A, Sastre-Garau X and Diop M. COFAC-Col: A Cervical Cancer Control Networking Initiative in Five French-Speaking African Countries. Cancer Epidemiol Biomarkers Prev. 2016; 25:1004-5. | Article | PubMed

22. Looker KJ, Magaret AS, Turner KM, Vickerman P, Gottlieb SL and Newman
LM. Correction: Global estimates of prevalent and incident herpes simplex virus type 2 infections in 2012. PLoS One. 2015; 10:e0128615. | Article | PubMed Abstract | PubMed FullText

23. Denny LA, Franceschi S, de Sanjose S, Heard I, Moscicki AB and Palefsky J. Human papillomavirus, human immunodeficiency virus and immunosuppression. Vaccine. 2012; 30 Suppl 5:F168-74. | Article | PubMed

24. Organisation mondiale de la santé, 2014. Lignesdirectrices de l'OMS. Lignesdirectrices de l'OMS pour le dépistageet le traitement des lesions précancéreuses pour la prévention du cancer du col de l'utérus. apps. who. int/iris/bitstream/10665/112555/1/9789242548693. (Consultation novembre 2016).

\section{Citation:}

Sako FB, Soumah MM, Bangoura MA, Tounkara TM, Traoré FA, Maiga A, Keita F, Diané BF, Keita M, Baldé H, Delamou A, Touré A and Cissé M. Epidemiologic and clinical profile of human Papilloma virus infection in the department of Dermatology-Venerology of the Donka National Hospital in Conakry, Guinea.

Res J Infect Dis. 2018; 6:1. http://dx.doi.org/10.7243/2052-5958-6-1 